\title{
PEMANFAATAN TANAMAN LOKAL SEBAGAI PELANCAR ASI (GALAKTOGOGUE)
}

\author{
Sri Handayani ${ }^{1}$, Yopi Suryatim Pratiwi ${ }^{*}$, Nurul Fatmawati ${ }^{3}$ \\ 1,2,3Prodi Kebidanan Program Sarjana STIKES Yarsi Mataram \\ *Korespondensi email: srikurniawan87@gmail.com
}

\section{ABSTRACT THE UTILIZATION OF LOCAL PLANTS AS A BREASTFEEDING TRANSFER (GALAKTOGUE)}

Background: Poor nutritional status is the cause of pneumonia and diarrhea in infants and toddlers. This incidence can be reduced through exclusive breastfeeding. The achievement of exclusive breastfeeding in Indonesia is still far from the national target, one of which is caused by the lack of breast milk production. In Indonesia, there are many plants that can promote breast milk, including katuk leaves, moringa leaves, young papaya fruit, wake-up, and fenugreek. The use of local plants as a breast milk facilitator must be supported by comprehensive information regarding the dosage form, dosage and duration of use, empirical benefits, and possible side effects.

Objective: The aim of the study was to describe the use of local plants as breast milk carriers (galactogogue). Method: The method in this research is quantitative. This research was conducted in Terong Tawah Village, Labuapi District, West Lombok Regency in April 2021. The sample in this study were all mothers who had babies aged 0-2 years, as many as 123 people. The instrument in this study used a questionnaire made on google form. The research was conducted by sending a questionnaire via WhatsApp message. The data obtained were analyzed by univariate.

Results: The results showed that the plants used to facilitate breastfeeding by the community were katuk leaves, moringa leaves, turi leaves, and spinach. These plants are processed by clear vegetable.

Conclusion: Plants used by the community are scientifically proven to increase breast milk production. Further research needs to be done, one of which is about processing clear vegetables.

Suggestion there is a need for further research on how to process clear vegetables so that they have the maximum effect.

Keywords: Breast milk, Galaktogogue, Clear Vegetable, Plants.

\section{ABSTRAK}

Latar belakang: Status gizi kurang merupakan penyebab kejadian pneumonia dan diare pada bayi dan Balita. Kejadian ini dapat diturunkan melalui pemberian ASI eksklusif. Capaian ASI eksklusif di Indonesia masih jauh dari target nasional, salah satunya disebabkan oleh produksi ASI kurang. Di Indonesia terdapat banyak tanaman yang dapat melancarkan ASI, diantaranya daun katuk, daun kelor, buah papaya muda, bangun-bangun, dan klabet. Penggunaan tanaman lokal sebagai pelancar ASI harus didukung informasi yang komprehensif terkait bentuk sediaan, dosis, lama penggunaan, manfaat empiris, dan kemungkinan efek samping.

Tujuan: Penelitian bertujuan untuk mengetahui gambaran pemanfaatan tanaman lokal sebagai pelancar ASI (galaktogogue).

Metode: Metode dalam penelitian ini adalah kuantitatif. Penelitian ini dilaksanakan di Desa Terong Tawah, Kecamatan Labuapi, Kabupaten Lombok Barat pada bulan April 2021. Sampel dalam penelitian ini adalah semua ibu yang memiliki bayi usia 0-2 tahun, yaitu sebanyak 123 orang. Instrumen dalam penelitian ini menggunakan kuesioner yang dibuat pada google form. Penelitian dilakukan dengan mengirimkan kuesioner melalui pesan whatsApp. Data yang diperoleh dianalisis secara univariat .

Hasil: Hasil penelitian menunjukkan tanaman yang dimanfaatkan untuk memperlancar ASI oleh masyarakat adalah daun katuk, daun kelor, daun turi,dan bayam. Tanaman tersebut diolah dengan cara disayur bening.

Kesimpulan: Tanaman yang digunakan masyarakat terbukti dapat memperlancar ASI.

Saran perlu adanya penelitian lanjutan, salah satunya tentang cara pengolahan sayur bening sehingga menimbulkan efek maksimal.

Kata Kunci: ASI, Galaktogogue, Sayur Bening,Tanaman. 


\section{JKM (Jurnal Kebidanan Malahayati),Vol 7,No.3.Juli 2021, ISSN (Print) 2476-8944 ISSN (Online) 2579-762X, Hal 518-522}

\section{PENDAHULUAN}

Kesehatan bayi dan Balita merupakan salah satu penentu indeks pembangunan kesehatan di Indonesia. Hasil Survei Demografi dan Kesehatan Indonesia (SDKI) tahun 2017 menunjukkan Angka Kematian Bayi (AKB) dan Angka Kematian Balita (AKABA) di Indonesia tahun 2017 masih tinggi, yaitu masing-masing sebesar 24/1000 KH dan $32 / 1000 \mathrm{KH}$. Angka ini masih di bawah target Sustainable Depelopment Goals (SDGs) ketiga, yaitu menekan angka kematian bayi menjadi 16/1000 KH tahun 2024 dan AKABA 18.8/1000 KH tahun 2030.

Berdasarkan data Profil Kesehatan Indonesia tahun 2019, angka kematian bayi di Indonesia terutama disebabkan oleh pneumonia dan diare, masing-masing sebesar 979 kematian $(15,9 \%)$ dan 746 kematian (12,1\%), sedangkan angka kematian Balita terbanyak disebabkan diare yaitu sebanyak 314 kematian $(10,7 \%)$.

Berdasarkan SDKI tahun 2012, AKB di Provinsi NTB adalah $57 / 1000 \mathrm{KH}$, masih jauh dari angka nasional, yaitu 32/1000 KH. Data pada Profil Kesehatan Provinsi Nusa Tenggara Barat tahun 2020, jumlah kematian bayi tahun 2019 sebanyak 863 kematian, dimana kasus kematian tertinggi berada di Kabupaten Lombok Timur, yaitu 288 kasus, disusul Lombok Tengah dan Bima masingmasing 204 dan 79 kasus.

Berdasarkan data pada Profil Kesehatan Provinsi Nusa Tenggara Barat tahun 2020, penyebab utama kematian bayi usia 29 hari sampai 11 bulan di Provinsi NTB tahun 2019 adalah pneumonia sebanyak 71 bayi dan diare 13 bayi. Demikian halnya dengan penyebab kematian anak Balita (usia 12 bulan sampai 59 bulan), juga disebabkan oleh pneumonia dan diare, masingmasing 11 dan 5 Balita. Pneumonia dan diare pada bayi dan Balita umumnya terjadi pada bayi dengan gizi kurang.

Penyebab kematian tersebut dapat dicegah dengan pemberian ASI. Sistematik review yang dilakukan Lamberti dkk $(2011,2013)$ menunjukkan pemberian ASI selama 6 bulan kehidupan bayi mampu mengurangi kesakitan dan kematian bayi akibat diare sampai bayi usia 2 tahun dan pemberian ASI selama 23 bulan kehidupan bayi merupakan kunci intervensi menekan morbiditas dan mortalitas karena pneumonia.

Berdasarkan data SDKI tahun 2017, capaian ASI eksklusif di Indonesia sebesar $52 \%$. Persentase ini meningkat dibandingkan data hasil SDKI tahun 2012, yaitu sebesar 42\%. Walaupun demikian, persentase tersebut masih jauh dari target yang ditetapkan pemerintah, yaitu $80 \%$.
Berdasarkan data Profil Kesehatan Provinsi NTB tahun 2020, cakupan pemberian ASI eksklusif rata-rata sebesar $80,13 \%$, dengan cakupan tertinggi di Kabupaten Lombok Tengah 92,11\%, sedangkan cakupan terendah di Kabupaten Dompu (46,39\%) dan disusul Kota Mataram (55,28\%).

Kegagalan pemberian ASI eksklusif salah satunya disebabkan persepsi ketidakcukupan ASI, dimana bisa disebabkan faktor fisiologis dan psikologis. Hasil penelitian yang dilakukan Fikawati dan Syafik (2012) menunjukkan hampir 50\% ibu menyusui di Kabupaten Karawang menghentikan ASI eksklusif karena merasa produksi ASI kurang.

Produksi ASI yang kurang disebabkan oleh faktor nutrisi dan hormon. Di Indonesia terdapat banyak tanaman yang dipercaya dapat meningkatkan produksi ASI (galaktogogue). Tanaman lokal yang ditetapkan dalam obat herbal asli Indonesia tahun 2016 sebagai galaktogogue antara lain, daun katuk (Sauropus androgynus), biji klabet (Trigonella foenum-graceum), dan daun jinten atau torbangun (Coleus ambonicius). Hasil review kualitatif yang dilakukan oleh Monika (2020) menunjukkan beberapa tanaman yang terbukti secara ilmiah dapat digunakan sebagai pelancar ASI adalah daun katuk, daun kelor, dan daun papaya.

Penggunaan tanaman lokal sebagai pelancar ASI belum didukung oleh informasi yang komprehensif terkait bentuk sediaan, dosis, lama penggunaan, manfaat empiris, dan kemungkinan efek samping. Oleh karena itu, perlu dilakukan penelitian tentang "Pemanfaatan Tanaman Lokal sebagai Pelancar ASI (Galaktogogue)".

\section{METODOLOGI PENELITIAN}

Metode yang digunakan dalam penelitian ini adalah kuantitatif, dimana untuk mengetahui gambaran yang akurat tentang penggunaan tanaman lokal sebagai pelancar ASI. Penelitian ini dilaksanakan di Desa Terong Tawah, Kecamatan Labuaapi, Kabupaten Lombok Barat pada bulan April 2021. Sampel dalam penelitian ini adalah semua ibu yang memiliki bayi usia 0-2 tahun, yaitu sebanyak 123 orang. Instrumen dalam penelitian ini menggunakan kuesioner yang dibuat pada google form. Penelitian dilakukan dengan mengirimkan kuesioner melalui pesan whatsApp. Responden yang tidak memiliki handphone dan tidak bisa menggunakan aplikasi whatsApp akan difasilitasi oleh peneliti dengan menggunakan handphone peneliti. Data yang diperoleh dianalisis secara univariat menggunakan program SPSS dan disajikan dalam bentuk distribusi frekuensi dan persentase. 


\section{HASIL DAN PEMBAHASAN}

Hasil penelitian tentang penggunaan tanaman lokal sebagai pelancar ASI dapat dilihat pada tabel berikut:

Tabel 1.

Distribusi Frekuensi Responden Berdasarkan Jenis Tanaman Lokal yang Digunakan sebagai Pelancar ASI (Galaktogogue) di Desa Terong Tawah, Kecamatan Labuapi, Kabupaten Lombok Barat Tahun 2021

\begin{tabular}{lcc}
\hline \multicolumn{1}{c}{ Jenis Tanaman } & $\mathbf{n}$ & $\%$ \\
\hline Daun Kelor & 47 & 38,2 \\
Daun Katuk & 62 & 50,4 \\
Daun Turi & 11 & 8,9 \\
Bayam & 3 & 2,4 \\
\hline \multicolumn{1}{c}{ Total } & 123 & 100 \\
\hline
\end{tabular}

Berdasarkan tabel 1, sebagian besar responden menggunakan daun katuk sebagai pelancar ASI, yaitu sebesar 62 responden $(50,4 \%)$ dan sebagian kecil menggunakan bayam, yaitu sebanyak 3 responden $(2,4 \%)$.

Tabel 2.

Distribusi Frekuensi Responden Berdasarkan Cara Pengolahan Tanaman Lokal yang Digunakan sebagai Pelancar ASI (Galaktogogue) di Desa Terong Tawah, Kecamatan Labuapi, Kabupaten Lombok Barat Tahun 2021

\begin{tabular}{lcc}
\hline \multicolumn{1}{c}{ Jenis Tanaman } & N & $\%$ \\
\hline $\begin{array}{l}\text { Daun Kelor } \\
\text { Sayur Bening }\end{array}$ & 47 & 100 \\
$\begin{array}{l}\text { Daun Katuk } \\
\text { Sayur Bening }\end{array}$ & 62 & 100 \\
$\begin{array}{l}\text { Daun Turi } \\
\text { Sayur Bening }\end{array}$ & 11 & 100 \\
$\begin{array}{l}\text { Bayam } \\
\text { Sayur Bening }\end{array}$ & 3 & 100 \\
\hline
\end{tabular}

Berdasarkan tabel 2, semua responden $(100 \%)$ mengolah tanaman lokal seperti daun kelor, daun katuk, daun turi dan bayam dengan cara disayur bening.

\section{PEMBAHASAN}

Tanaman yang digunakan oleh masyarakat Desa Terong Tawah sebagai pelancar ASI secara ilmiah sudah terbukti dapat meningkatkan produksi ASI. Tanaman yang dimanfaatkan adalah daun katuk, daun kelor, daun turi, dan bayam. Tanaman tersebut diolah dengan cara disayur bening.
Daun katuk (Sauropus androgynus (L.) Merr) merupakan salah satu tanaman lokal yang banyak ditanam oleh penduduk Lombok. Sebagian besar masyarakat $(50,4 \%)$ menggunakan daun katuk untuk meningkatkan produksi ASI. Daun katuk terbukti aman, dimana uji toksisitas akut dan terpatogenik pada mencit menunjukkan bahwa daun katuk tidak toksik dan tidak menimbulkan kecacatan pada janin (Wuryaningsih, 1997). Uji toksisitas pada hewan coba tikus betina galur wistar menggunakan sediaan suspensi daun katuk dengan empat macam dosis yang berbeda, yaitu 500, 1000, 3000 , dan $5000 \mathrm{mg} / \mathrm{Kg}$ BB tikus menghasilkan Letal Doses ( $\left(\mathrm{LD}_{50}\right)$ di atas $5000 \mathrm{mg} / \mathrm{Kg}$ BB sehingga dapat dikatakan daun katuk bersifat tidak toksik (Eng Khoo, 2015).

Penelitian tentang khasiat daun katuk sebagai pelancar air susu juga sudah banyak dilakukan di Indonesia. Pemberian ekstrak daun katuk pada mencit secara signifikan meningkatkan ekspresi gen oksitosin (Soka, 2010). Ekspresi gen oksitosin pada mencit menyusui dengan dosis $173,6 \mathrm{mg} / \mathrm{kg}$ dan $868 \mathrm{mg} / \mathrm{kg}$ BB ekstrak daun katuk tua pada mencit meningkat secara signifikan masing-masing 22,02 kali lipat dan 46,39 kali lipat. Tingkat ekspresi gen prolaktin pada kelompok mencit dengan dosis $173,6 \mathrm{mg} / \mathrm{kg}$ berat badan ekstrak daun katuk tua meningkat secara signifikan 14,65 kali lipat, sedangkan kelompok kedua dengan dosis $868 \mathrm{mg} / \mathrm{kg}$ meningkat secara signifikan 2,42 kali lipat (Soka, 2011).

Penelitian efek farmakologi membuktikan ekstrak daun katuk dosis $631,6 \mathrm{mg} / \mathrm{kg}$ BB menunjukkan efek laktagogum pada tikus. Pemberian ekstrak daun katuk dengan dosis $3 \times 300$ selama 15 hari postpartum dapat meningkatkan produksi ASI sebesar $66,7 \mathrm{ml}$ atau $50,7 \%$ lebih banyak dibandingkan dengan ibu yang tidak diberi ekstrak daun katuk. Pemberian ekstrak daun katuk juga menurunkan jumlah subjek kurang ASI sebanyak 12,5\% (31,25\%-19,75\%) (Sa'roni, 2004). Penelitian lain dengan pemberian ekstrak daun katuk dosis 2×1@500mg selama 7 hari postpartum menunjukkan terdapat pengaruh yang signifikan pada pemberian ekstrak daun katuk terhadap produksi ASI (Nindiyaningrum, 2014).

Produksi ASI yang meningkat pada pemanfaatan daun katuk disebabkan daun katuk mengandung senyawa aktif, yaitu sterol (fitosterol) (Subekti, 2007) dan alkaloid (papaverin) (Soka,2011), yang dapat meningkatkan kadar prolaktin yang berperan dalam pembentukan ASI dan oksitosin yang berperan dalam pengeluaran ASI, serta mengandung zat gizi yang dapat 


\section{JKM (Jurnal Kebidanan Malahayati),Vol 7,No.3.Juli 2021, \\ ISSN (Print) 2476-8944 ISSN (Online) 2579-762X, Hal 518-522}

digunakan sebagai bahan baku pembuatan ASI (Sa'roni, 2004).

Daun katuk mengandung protein yang paling tinggi dibandingkan dengan sayuran yang lain. Dalam $100 \mathrm{~g}$ daun katuk segar mengandung air $79,8 \mathrm{~g}$, protein $7,6 \mathrm{~g}$, lemak $1,8 \mathrm{~g}$, karbohidrat $6,9 \mathrm{~g}$, serat $1,9 \mathrm{~g}$, abu $2,0 \mathrm{~g}$, vitamin $\mathrm{A} 10000 \mathrm{IU}$, vitamin B1 0,23 mg, vitamin B2 0,15 mg, vitamin C $136 \mathrm{mg}$, Ca $234 \mathrm{mg}, \mathrm{P} 64 \mathrm{mg}, \mathrm{Fe} \mathrm{3,1} \mathrm{mg,} \mathrm{dan} \mathrm{nilai} \mathrm{energi}$ 310 kJ (Bergh, 1994). Kandungan ini merupakan penunjang nilai gizi daun katuk yang bermanfaat bagi ibu yang sedang menyusui.

Hasil penelitian menunjukkan seluruh ibu menyusui (100\%) mengonsumsi tanaman daun katuk dengan cara disayur bening. Penelitian Sitmorang (2019) membuktikan konsumsi air rebusan daun katuk dengan campuran 300 gram daun katuk dan 1,5 liter air, selama 15 menit, mampu melancarkan ASI. Penelitian Wulandari (2020) menyebutkan hanya dibutuhkan waktu 3 menit saja sejak air mendidih untuk merebus daun katuk. Masyarakat biasanya memasak daun katuk adalah dengan merebusnya hingga empuk dan terbuka sehingga kandungan gizi yang terkandung berkurang.

Tanaman kelor (Moringa oleifera) banyak ditanam dan ditemukan di perumahan penduduk Lombok. Penelitian yang dilakukan menunjukkan $30,8 \%$ masyarakat menggunakan daun kelor untuk meningkatkan ASI dan diolah dengan disayur bening.

Daun kelor mirip dengan daun katuk, daunnya enak dimakan menjadi beragam masakan. Daun kelor juga terbukti aman, dimana uji toksisitas subkronis digunakan tikus putih (Rattus norvegicus), galur wistar sebanyak 40 ekor yang dibagi dalam 4 kelompok dosis. Hasil penelitian perhitungan LD50 ekstrak biji klabet dan daun kelor (1:1) menghasilkan harga LD50 semu $>4.000$ $\mathrm{mg} / 200 \mathrm{~g} \mathrm{bb}$ sehingga campuran bahan tersebut termasuk dalam golongan bahan practically non toxic (PNT). Pada uji toksisitas subkronis pemberian ramuan ekstrak klabet dan kelor (1:1) masih menunjukkan keadaan normal pada fungsi hati dan ginjal (Widowati, 2013).

Hasil penelitian Mutiara (2011) menunjukkan pemberian tepung kelor dapat meningkatkan produksi air susu induk tikus secara signifikan. Pemberian dosis mulai $42 \mathrm{mg} / \mathrm{kg}$ bb secara signifikan dapat membuat sekresi air susu tikus putih meningkat dan berat badan anak tikus meningkat seiring dengan meningkatnya dosis yang diberikan.

Produksi ASI yang meningkat pada pemanfaatan daun kelor karena kandungan gizi dan senyawa aktif. Setiap $100 \mathrm{~g}$ daun kelor mengandung $3390 \mathrm{SI}$ vitamin A, dua kali lebih tinggi dari bayam dan tiga puluh kali lebih tinggi dari buncis. Daun kelor juga tinggi kalsium, sekitar 440 $\mathrm{mg} / 100 \mathrm{~g}$, serta fosfor $70 \mathrm{mg} / 100 \mathrm{~g}$ (Djaiman, 2009). Zat gizi sangat berperan sebagai bahan baku pembentukan ASI. Hasil uji secara kualitatif tepung daun kelor mengandung senyawa steroid yang berperan dalam produksi ASI (Mutiara, 2011). Aroma daun kelor agak langu, namun aroma berkurang ketika daun mudanya diolah menjadi sayur bening.

Daun turi dan daun bayam juga terbukti meningkatkan produksi ASI. Hasil penelitian yang dilakukan Widiyati (2009) menunjukkan pemberian ekstrak daun turi (Sesbania grandiflora L.) mampu meningkatkan sekresi air susu dan diameter alveolus kelenjar ambing mencit (Mus musculus). Penelitian yang dilakukan Kuswaningrum dkk (2017) menunjukkan pemberian kapsul ekstrak daun bayam (Amaranthus spinous L.) $1400 \mathrm{mg}$ perhari (pagi, siang, dan malam) mampu meningkatkan tingkat prolaktin dan produksi ASI pada ibu nifas. Peningkatan produksi ASI disebabkan daun turi dan bayam mengandung senyawa phenol. Polyphenol berperan dalam meningkatkan tingkat prolaktin. Prolaktin yang tinggi meningkatkan produksi ASI.

\section{SIMPULAN}

Berdasarkan hasil penelitian menunjukkan masyarakat Desa Terong Tawah, Kecamatan Labuapi, Kabupaten Lombok Barat memanfaatkan tanaman lokal sebagai pelancar ASI, diantaranya daun katuk, daun kelor, daun turi, dan bayam. Secara ilmiah, tanaman tersebut terbukti dapat melancarkan produksi ASI. Penggunaan tanaman lokal sebagai pelancar ASI harus didukung informasi yang komprehensif terkait bentuk sediaan, dosis, dan lama penggunaan, manfaat empiris, dan kemungkinan efek samping.

\section{SARAN}

Perlu adanya penelitian lanjutan, salah satunya tentang cara pengolahan sayur bening sehingga menimbulkan efek maksimal.

\section{DAFTAR PUSTAKA}

Bergh MVD. Sauropus androgynus (L.) Merrill In: Siemonsma, J.S. \& Piluek, K (eds.):Plant Reources of South-East Asia No. 8 Vegetables. Prosea Fondation Bogor, Indonesia 1994:244-6. 
Dinas Kesehatan Provinsi NTB. Profil Kesehatan Provinsi NTB 2020. Matarm: Dinas Kesehatan Provinsi NTB. 2020.

Djaiman SPH, Sihadi. Besarnya peluang usia penyapihan baduta di Indonesia dan factor yang mempengaruhinya. Media Litbang Kesehatan. 2009; 19(1).

Eng Khoo H, Azlan A, Ismaila A. Sauropus androgynus Leaves for Health Benefits: Hype and the Science. The Natural Products Journal. 2015;5(2):115-23.

Fikawati S, Syafiq A. Status Gizi Ibu dan Persepsi Ketidakcukupan Air Susu Ibu. Kesmas: Jurnal Kesehatan Masyarakat Nasional. 2012;6(6).

Kementerian Kesehatan RI. Profil Kesehatan Indonesia 2019. Jakarta: Kementerian Kesehatan Republik Indonesia. 2019.

Kementerian Kesehatan RI. Survei Demografi dan Kesehatan Indonesia (SDKI) 2017. Jakarta: Badan Penelitian dan Pengembangan Kesehatan Kementerian RI. 2017.

Kementerian Kesehatan RI. Survei Demografi dan Kesehatan Indonesia (SDKI) 2012. Jakarta: Badan Penelitian dan Pengembangan Kesehatan Kementerian RI. 2012.

Lamberti et al. Breastfeeding and the risk for diarrhea morbidity and mortality. BMC Public Health 2011, 11(Suppl 3):S15.

Lamberti et al. Breastfeeding for reducing the risk of pneumonia morbidity and mortality in children under two: a systematic literature review and meta-analysis. BMC Public Health 2013, 13(Suppl 3):S18.

Monika, NLGM. Potensi Tanaman Lokal sebagai Galaktagogue Herbal untuk Meningkatkan Produksi ASI.Jurnal Emasains: Jurnal Edukasi Matematika dan Sains Volume IX Nomor 1 Maret Tahun 2020 Hal : 104 - 112.

Mutiara T. Uji Efek Pelancar ASI Tepung Daun Kelor (Moringa oleifera (Lamk))Pada Tikus Putih Galur Wistar. Universitas Brawijaya. 2011.

Nindiyaningrum RA. Pengaruh Pemberian Ekstrak Daun Katuk Terhadap Produksi ASI pada Ibu Post Partum. Jurnal IImu Keperawatan dan Kebidanan. 2014;1(6).

Sa'roni, Sadjiman T, Sja'bani M, Zulaela Z. Effectiveness of the Sauropus androgynus (l.) Merr leaf extract in increasing mother's breast milk production. Media Penelitian dan Pengembangan Kesehatan. 2004;14(3 Sept).
Sitmorang TS, Br. Singarimbun AP. Pengaruh Konsumsi Air Rebusan Daun Katuk terhadap Pengeluaran Produksi ASI pada Ibu Nifas di Bidan Praktek Mandiri Manurung Medan Tahun 2018.Indonesian Trust Health Journal Volume 1 - No. 2 - April 2019.

Soka S, Alam H, Boenjamin N, Agustina T, Suhartono M. Effect of Sauropus androgynus leaf extracts on the expression of prolactin and oxytocin genes in lactating BALB/C mice. Journal of nutrigenetics and nutrigenomics. 2010;3(1):31-6.

Soka S, Wiludjaja J, Marcella. The Expression of Prolactin and Oxytocin Genes in Lactating BALB/C Mice Supplemented with Mature Sauropus androgynus Leaf Extracts. International Conference on Food Engineering and Biotechnology. 2011;9.

Subekti S. Komponen sterol dalam ekstrak daun katuk (Sauropus androgynus) dan hubungannya dengan sistem reproduksi puyuh. 2007.

Wulandari ET, Wardani WK. Gambaran Penggunaan Herbal Pelancar ASI (Galaktogogues) di Desa Wonosari Kabupaten Pringsewu. Wellness and Healthy Magazine Volume 2, Issue 2, Agustus 2020, p. $251-258$.

Wuryaningsih LE, Eva MD, Widayat S. Uji teratogenik infusa daun katuk pada mencit hamil. Warta Tumbuhan Obat Indonesia. 1997;3(3).

Widiyati, SW. 2009. Pengaruh Pemberian Ekstrak Daun Turi (Sesbania grandiflora L.) terhadap Jumlah Sekresi Air Susu dan Diameter Alveolus Kelenjar Ambing Mencit(Mus Musculus). Skripsi,Jurusan Biologi Fakultas Sains dan Teknologi UIN Malang.

Kuswaningrum O, Suwandono A, Ariyanti A, Hadisaputro $S$, Suhartono. The Impact of Consuming Amaranthus Spinosus L. Extract on Prolactin Level and Breast Milk Production in Postpartum Mothers. Belitung Nursing Journal,Volume 3, Issue 5, SeptemberOctober 2017.

Widowati L, Winarno MW, Intan PR.Toksisitas Akut dan Subkronis Ramuan Ekstrak Kelor dan Klabet sebagai Pelancar ASI dan Penambah Gizi. Jurnal Kefarmasian Indonesia Vol. 43.2.2014:5164. 